\title{
CUMENE HYDROPEROXIDE-SUPPORTED DENITRIFICATION OF 2-NITROPROPANE IN UNINDUCED MOUSE LIVER MICROSOMES
}

\author{
Elizabeth K. Marker* and Arun P. Kulkarni $\dagger$ \\ Toxicology Program, Department of Environmental and Industrial Health, School of Public Health, \\ The University of Michigan, Ann Arbor, MI 48109, U.S.A.
}

(Received 25 November 1985)

\begin{abstract}
Cumene hydroperoxide supported oxidative denitrification of 2-nitropropane was investigated in uninduced mouse liver microsomes.

2. The cytochrome $P-450$ peroxygenase catalyzed reaction resulted in the production of nitrite and acetone.

3. Several lines of evidence suggested the involvement of multiple forms of cytochrome $P-450$.

4. Acetone production was at least two times greater than nitrite release possibly due to sequestration of nitrite in the reaction mixtures.
\end{abstract}

\section{INTRODUCTION}

The metabolism of nitro-containing compounds by mammalian systems has been an area of study for many years. Earlier, the focus was on the reduction of the nitro group classically illustrated by $p$-nitrobenzoic acid reduction to $p$-aminobenzoic acid (Fouts and Brodie, 1957). Oxidative metabolism of 2-nitropropane (2NP) by rat liver microsomes was demonstrated by Ullrich et al. (1978). This novel reaction involved cytochrome $P-450(P 450)$ mediated denitrification of 2NP to yield nitrite and acetone as products. The involvement of $P 450$ was substantiated by an increase in nitrite release after phenobarbital (PB) and 3-methylcholanthrene (3MC) induction, in vitro inhibition by metyrapone, $\alpha$-naphthoflavone and carbon monoxide (CO), and reversal of $\mathrm{CO}$ inhibition by monochromatic light at $450 \mathrm{~nm}$. The importance of this reaction was amplified in a subsequent study (Sakurai et al., 1979) which demonstrated the applicability of this reaction mechanism to other aliphatic nitro compounds. In contrast to the essential absence of denitrification activity reported by Ullich et al., (1978) for hepatic microsomes from untreated rats, our work with 2NP in an NADPH-dependent system (Marker and Kulkarni, 1985, 1986) has shown significant nitrite releasing ability in uninduced $\mathrm{CD}_{1}$ mouse liver microsomes. That this activity was observed without induction of $P 450$ by chemical pretreatment enhances the potential toxicological significance of hepatic 2NP metabolism. A similar reaction has also been reported in rabbit liver microsomes for 2-nitro-1-phenylpropane (Jonsson et al., 1977).

A few studies have reported reductive microsomal denitrosation of nitrosamines (Appel et al., 1980; Appel and Graf, 1982). Appel and Graf (1982) demonstrated nitrite release from nitrosamines in a

*Present address: Department of Clinical Pathology, The Oregon Health Sciences University, Portland, OR 97201, U.S.A.

†Author to whom correspondence should be addressed. reconstituted microsomal $P 450$ system from PB induced pig liver. Spectral binding studies reported by these authors suggested a mechanism involving reductive cleavage of the nitroso group with a secondary amine as the leaving group. The nitroso group was thought to remain bound to the reduced $P 450$ as nitric oxide which was non-enzymatically displaced from its binding site by molecular oxygen. The liberated nitric oxide was then partially converted to nitrite.

The report of Ullrich et al. (1978) retains some ambiguity as to the reaction mechanism of $2 \mathrm{NP}$ metabolism. The authors noted that lowering the oxygen concentration from 21 to $4 \%$ had no effect on the rate of 2NP denitrification which led them to believe that reduction of the nitro group to an amine was unlikely to occur. In theory, however, if oxidation is the only pathway involved in the metabolism of 2NP then a low oxygen concentration should have caused a proportional decrease in $P 450$-dependent oxidative nitrite release. Thus, it was not clear whether the reaction was exclusively oxidative. The failure to observe the oxygen dependence of the reaction suggests the possibility that at least part of the nitrite release from 2NP in the NADPH-coupled reaction was through an oxygenindependent mechanism(s). This has also been suggested by investigations on 2NP denitrification in an NADPH-dependent mouse microsomal system (Marker and Kulkarni, 1986).

In order to establish unequivocally that denitrification of 2NP can proceed by an oxidative mechanism, the reaction was evaluated using mouse hepatic microsomes supplemented with cumene hydroperoxide (CHP). Organic hydroperoxides, through the peroxygenase activity of $P 450$, can replace NADPH, NADPH cytochrome $P 450$ reductase, and molecular oxygen in numerous types of P450-mediated reactions (O'Brien, 1978). When $P 450$ acts as a peroxygenase the ferric ion in the active site remains in an oxidized state throughout the reaction cycle and, in the case of $2 \mathrm{NP}$, any nitrite 
release or acetone production would be due to a totally oxidative reaction. In this communication we report CHP-supported denitrification of $2 \mathrm{NP}$ in uninduced $\mathrm{CD}$, mouse liver microsomes.

\section{MATERIALS AND METHODS}

\section{Chemicals}

2NP $(94 \%)$, metyrapone (2-methyl-1,2-di-3-pyridyl-1propanone) and $\alpha$-naphthoflavone were obtained from Aldrich Chemical Co., Milwaukee, Wis. HEPES $(N-2$ hydroxyethyl piperazine- $N^{\prime}$-2-ethane sulfonic acid, sodium salt) was supplied by U.S. Biochemical, Cleveland, Ohio while imidazole was purchased from Eastman, Rochester, N.Y. Sigma Chemical Co., St Louis, Mo. supplied Tris(hydroxymethyl)aminomethane, $\mathrm{HCl}$ (Tris), glycine, and mixed isomers of butylated hydroxyanisole (BHA). SKF525A (2-diethylaminoethyl-2,2-diphenylvalerate, $\mathrm{HCl}$ ) was the generous gift of Smith, Kline and French, Philadelphia, $\mathrm{Pa}$. Metyrapone (2-methyl-1,2-di-3-pyridylpropane) and $\alpha$-naphthoflavone were obtained from Aldrick. CHP was purchased from Matheson, Coleman and Bell, Cincinnati, Ohio. The hydrochloride salt of $n$-octylamine was synthesized in the laboratory. All other chemicals were reagent grade and available commercially.

\section{Animals}

Male $C D_{1}$ mice were obtained from Charles River Breeding Laboratories, Portage, Mich. Mice were maintained on a $12 \mathrm{hr}$ light/dark cycle and allowed to acclimate for one week after receipt. Food and water were available ad libitum. All mice were between 8 and 14 weeks of age at sacrifice.

\section{Isolation of microsomes}

Mice were sacrificed by cervical dislocation and livers quickly removed, weighed, placed in $15 \mathrm{ml}$ ice cold homogenization buffer consisting of $50 \mathrm{mM}$ Tris, $0.1 \mathrm{mM}$

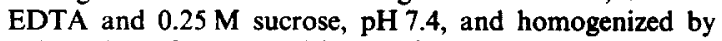
$6-8$ strokes of a motor driven Teflon pestle in a precooled glass mortar. The homogenate $(15-20 \%)$ was centrifuged at $4^{\circ} \mathrm{C}$ for $20 \mathrm{~min}$ at $9000 \mathrm{~g}$ to remove cell debris and mitochondria. The post-mitochondrial supernatant was centrifuged at $4^{\circ} \mathrm{C}$ for $60 \mathrm{~min}$ at $106,000 \mathrm{~g}$. The cytosol was discarded and the microsomal pellet washed by resuspension in a fresh $15 \mathrm{ml}$ aliquot of ice cold homogenization buffer, followed by recentrifugation at $106,000 \mathrm{~g}$ for $60 \mathrm{~min}$. The washed microsomes were resuspended in $2.0 \mathrm{ml}$ sucrose $(0.25 \mathrm{M})$.

\section{CHP-supported enzyme assay}

After protein determination by the Biuret method (Gornall et al., 1949) microsomes were diluted to a concentration of $2.0 \mathrm{mg}$ of protein $/ \mathrm{ml}$ in the specified buffer. Preliminary experiments indicated that, when CHP was included, the presence or absence of microsomes inactivated by boiling $\left(10 \mathrm{~min}\right.$ at $\left.100^{\circ} \mathrm{C}\right)$ had no effect on non-enzymatic nitrite release from $2 \mathrm{NP}$. Therefore, experiments were performed using control incubations containing $0.9 \mathrm{ml}$ of the specified buffer to which all other reaction components except microsomes were added. Total activity was assayed in a flask containing $1.0 \mathrm{mg} / \mathrm{ml}$ active microsomal protein, the indicated concentrations of 2NP and CHP, and the specified buffer. Final volume of the complete reaction system was $1.0 \mathrm{ml}$ for both the control (non-enzymatic) and total activity systems. Concentrations reported for reaction components are final concentrations.

All flasks were pre-incubated at $37 \pm 1^{\circ} \mathrm{C}$ in a shaking water bath for $5 \mathrm{~min}$. Following the addition of $2 \mathrm{NP}$ the reaction was initiated with CHP. The incubation time was 5 min after the addition of CHP unless otherwise specified. Nitrite was determined by a slight modification of the method described by Ullrich et al. (1978). The reaction was terminated by the removal of $0.5 \mathrm{ml}$ of the reaction mixture to $0.5 \mathrm{ml}$ ice cold zinc acetate $(0.5 \mathrm{M}$ in $50 \%$ ethanol) followed by the addition, while vortexing, of $0.5 \mathrm{ml}$ ice cold $0.5 \mathrm{M}$ sodium carbonate. The precipitate formed was removed by centrifugation at $2750 \mathrm{~g}$ for $5 \mathrm{~min}$. A $0.5 \mathrm{~m}$ ! aliquot of the clear supernatant was mixed with $1.0 \mathrm{ml}$ sulfanilamide $(2 \%$ in $6 \mathrm{~N} \mathrm{HCl})$ followed by $0.25 \mathrm{ml}$ $N$-(1-naphthyl)ethylenediamine $(0.16 \%$ in $6 \mathrm{~N} \mathrm{HCl})$. After $15 \mathrm{~min}$, absorbance of the colored product was measured at $540 \mathrm{~nm}$. Enzymatic nitrite release was quantified from the difference between the total activity flask and the nonenzymatic activity flask. Standard curves were prepared using sodium nitrite under identical conditions.

\section{Identification and quantification of acetone}

Acetone was identified as the second oxidation product of 2NP by gas liquid chromatography (GC). All reaction components with the exception of $2 \mathrm{NP}$ and CHP were placed in $10 \mathrm{ml}$ serum bottles kept on ice. After capping and sealing, the vials were preincubated at $37 \pm 1^{\circ} \mathrm{C}$ for $5 \mathrm{~min}$ in a shaking water bath. The reaction was started by introducing 2NP (105 mM) through the rubber stopper with a Hamilton syringe followed by CHP $(3.0 \mathrm{mM})$. (Optimal concentrations of $2 \mathrm{NP}$ were not used due to its interference with elution of the internal standard at the chromatography step.) After $5 \mathrm{~min}$ further incubation the reaction was stopped by addition through the stopper of $1.0 \mathrm{ml}$ ice-cold $0.5 \mathrm{M}$ aqueous zinc acetate. Vials were then placed on ice and the internal standard (IS) methylethylketone (MEK) (112 $\mathrm{nmol} /$ vial) was added. Vials remained on ice until head space analysis was performed.

GC was performed on a Varian 3700 chromatograph equipped with a flame ionization detector. Separation of the volatile components in the head space was achieved using a stainless steel column $\left(6^{\prime} \times 1 / 8^{\prime \prime}\right.$ o.d. $)$ prepacked with $0.1 \%$ SP-1000 on $80 / 100$ Carbopack C. The carrier gas was nitrogen with a flow rate of $24 \mathrm{ml} / \mathrm{min}$. GC conditions were as follows: injector temperature, $150^{\circ} \mathrm{C}$; detector temperature, $170^{\circ} \mathrm{C}$; initial column temperature, $40^{\circ} \mathrm{C}$; attenuation, $4 \times 10^{-12}$. The GC was programmed to hold the initial temperature for $5 \mathrm{~min}$ and then increase temperature $10^{\circ} \mathrm{C} / \mathrm{min}$ to $150^{\circ} \mathrm{C}$ which was held for $10 \mathrm{~min}$. For head space analysis, each vial was individually incubated for $30 \mathrm{~min}$ at $37 \pm 1^{\circ} \mathrm{C}$ and $1 \mathrm{ml}$ sample of the head space gas containing acetone was injected on column.

A Finnegan mass spectrometer was used to confirm the presence of acetone as second product of the CHP. supported reaction. A purge and trap method was used to introduce volatiles dissolved in the reaction mixture onto the GC column interfaced with the mass spectrometer. The trap was a glass column $10^{\prime \prime} \times 1 / 4^{\prime \prime}$ o.d. containing (in order from the inlet) silica gel, Tenax GC, and activated charcoal. The reaction mixture was purged into the cold trap by bubbling helium through the reaction mixture at $40 \mathrm{ml} / \mathrm{min}$ for $12 \mathrm{~min}$. The trap was then desorbed for $2 \mathrm{~min}$ at $200^{\circ} \mathrm{C}$ onto the GC column. This column was a $6^{\prime} \times 2 \mathrm{~mm}$ i.d. packed column containing $0.1 \%$ SP- 1000 on $80 / 100$ Carbopack C. The column was maintained at room temperature during the trap desorbtion. For this chromatography phase the flow rate of helium was $20 \mathrm{ml} / \mathrm{min}$. Chromatography was begun at $50^{\circ} \mathrm{C}$ held for $2 \mathrm{~min}$, and the temperature then increased at $8^{\circ} \mathrm{C} / \mathrm{min}$ until $2 \mathrm{NP}$ appeared at which time the run was terminated.

Acetone standards were made for each assay in buffer and microsomes and were run through the assay procedure as if they were test samples except that $\mathrm{CHP}$ was excluded. Acetone from these standards eluted at a retention time of $3.6 \mathrm{~min}$ while MEK had a retention time of $9.7 \mathrm{~min}$. Vials in which metabolism of $2 \mathrm{NP}$ occurred also contained a peak eluting at the same retention time as acetone. The peak height ratio of acetone to MEK in the samples increased with reaction time suggesting that acetone is an enzymatic reaction product. Quantification of acetone was by com- 


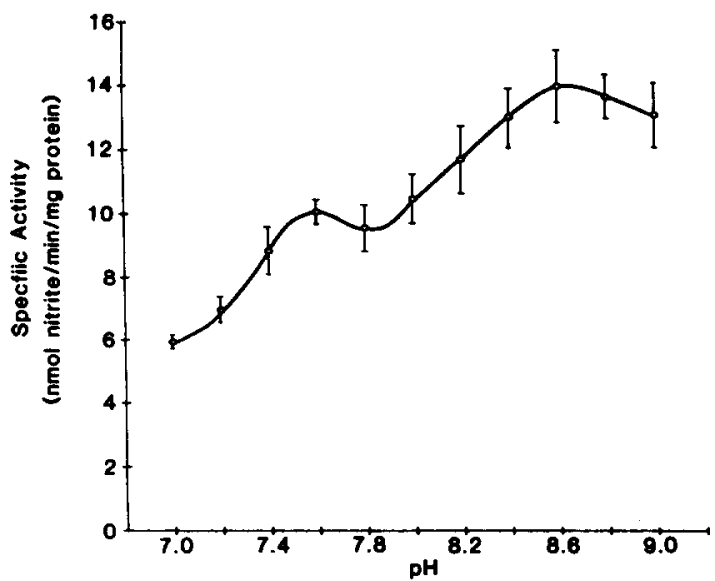

Fig. 1. CHP-supported denitrification of $2 \mathrm{NP}$ as a function of $\mathrm{pH}$. Assay conditions: buffer, $0.1 \mathrm{M}$ Tris; CHP, $4.0 \mathrm{mM}$; microsomal protein, $1.0 \mathrm{mg} / \mathrm{ml} ; 2 \mathrm{NP}, 157 \mathrm{mM}$; incubation time, $5 \mathrm{~min}$. Each point represents mean specific activity $\pm \operatorname{SE}(n=4)$. Specific activity is expressed as nmol of nitrite released $/ \mathrm{min} / \mathrm{mg}$ protein.

parison of peak height ratios (corrected for non-enzymatic activity) with known acetone standards.

\section{Statistics}

Unless otherwise noted, results are reported as mean specific activity \pm SE. Specific activity is defined as nanomoles of nitrite released or acetone produced $/ \mathrm{min} / \mathrm{mg} \mathrm{mi-}$ crosomal protein. Characterization experiments were performed with microsomes isolated from four pooled livers. In this case, a minimum of two replicate assays were done. All other observations are based on the indicated number of separate liver preparations.

Statistical analysis of CHP concentration dependence was by multiple comparisons using the Scheffe method (Remington et al., 1970). In the inhibitor study, statistical differences between treatments were tested using Student's $t$-test. In both cases a $P$ value of 0.05 or less was considered significant.

\section{RESULTS}

Similar to the NADPH and oxygen dependent reaction reported for hepatic microsomes from $\mathrm{PB}$ or 3MC induced rats (Ullrich et al., 1978) and uninduced mice (Marker and Kulkarni, 1985, 1986) nitrite release from $2 \mathrm{NP}$ was observed when uninduced male $\mathrm{CD}_{1}$ mouse hepatic microsomes were supplemented with CHP. Through a series of experiments, the CHP-supported reaction was characterized and the results are presented in the accompanying figures and tables.

The effect of $\mathrm{pH}$ on denitrification activity is illustrated in Fig. 1. The major activity peak was seen at $\mathrm{pH} 8.6$ with a shoulder at $\mathrm{pH}$ 7.6. These results correlate well with those found in our investigations of the NADPH-dependent reaction in uninduced mice (Marker and Kulkarni, 1986) and in induced rats (Ullich et al., 1978). Consequently, all further experiments were conducted at both $\mathrm{pH} 7.6$ and 8.6. The effect of different buffers at two $\mathrm{pHs}$ on relative nitrite releasing activity was studied. Considering both $\mathrm{pHs}$, relative activity was from 9 to $58 \%$ greater in $0.1 \mathrm{M}$ Tris than in HEPES buffer, sodium or potassium phosphate buffers, potassium chloride/ boric acid/NaOH buffer, or glycine/ $\mathrm{NaOH}$ buffer. Therefore, $0.1 \mathrm{M}$ Tris was used in all subsequent experiments.

To determine the optimal concentration of CHP for denitrification, a range from 0.1 to $10.0 \mathrm{mM}$ were tested. At pH 7.6 nitrite release was marginally greater at $2.0 \mathrm{mM}$ than at $3.0 \mathrm{mM}$, while at $\mathrm{pH} 8.6$, $3.0 \mathrm{mM}$ was slightly greater than $2.0 \mathrm{mM}$. Since no statistical difference among the values was observed from 1.0 to $5.0 \mathrm{mM} \mathrm{CHP}$ at $\mathrm{pH} 7.6$ or $\mathrm{pH} 8.6$, $3.0 \mathrm{mM}$ CHP was used for all subsequent experiments. Higher concentrations $(>5 \mathrm{mM})$ were less effective.

Substrate (2NP) concentration optima were found to be $262 \mathrm{mM}$ at $\mathrm{pH} 7.6$ and $157 \mathrm{mM}$ at $\mathrm{pH} 8.6$ (Fig. 2). The apparent $K_{m}$ values determined from

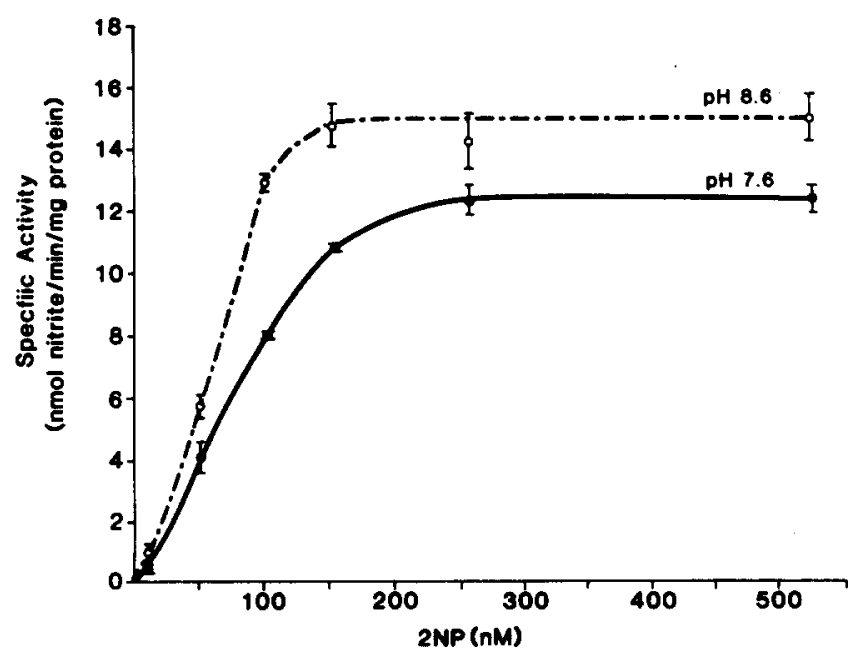

Fig. 2. Denitrification activity as a function of 2NP concentration. Assay conditions: buffer, $0.1 \mathrm{M}$ Tris; $\mathrm{pH}$, as indicated; CHP, $3.0 \mathrm{mM}$; microsomal protein, $1.0 \mathrm{mg} / \mathrm{ml}$; incubation time, $5 \mathrm{~min}$. Each point represents mean specific activity $\pm \mathrm{SE}(n \geqslant 3)$. Specific activity is expressed as nmol of nitrite released $/ \mathrm{min} / \mathrm{mg}$ protein. 


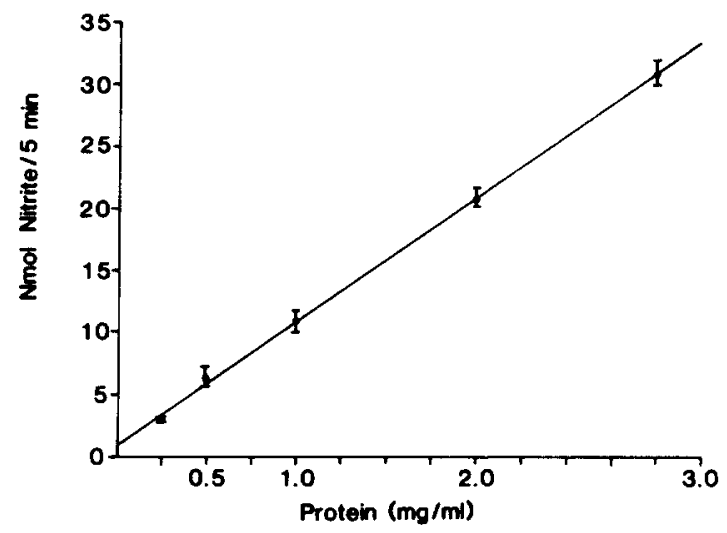

Fig. 3. Effect of microsomal protein concentration on denitrification of 2NP. Assay conditions: buffer, $0.1 \mathrm{M}$ Tris; $\mathrm{pH}, 7.6$; 2NP, $262 \mathrm{mM}$; CHP $3.0 \mathrm{mM}$; incubation time, 5 min. Each point represents mean activity $\pm S E(n=4)$. Activity is expressed as $\mathrm{nmol}$ of nitrite released $/ 5 \mathrm{~min}$. Similar linear response was observed when assays were performed at $\mathrm{pH} 8.6$ (not shown).

these data were $83 \mathrm{mM}$ at $\mathrm{pH} 7.6$ and $65 \mathrm{mM}$ at $\mathrm{pH}$ 8.6. In addition, the CHP-supported reaction was found to be linear with respect to protein concentration up to $3.0 \mathrm{mg} / \mathrm{ml}$ at both pHs (Fig. 3).

Time dependence of the reaction was also assessed and linearity was observed up to $15 \mathrm{~min}$ at $\mathrm{pH} 7.6 \mathrm{but}$ only up to $7.5 \mathrm{~min}$ at $\mathrm{pH} 8.6$ (Fig. 4). Non-linearity
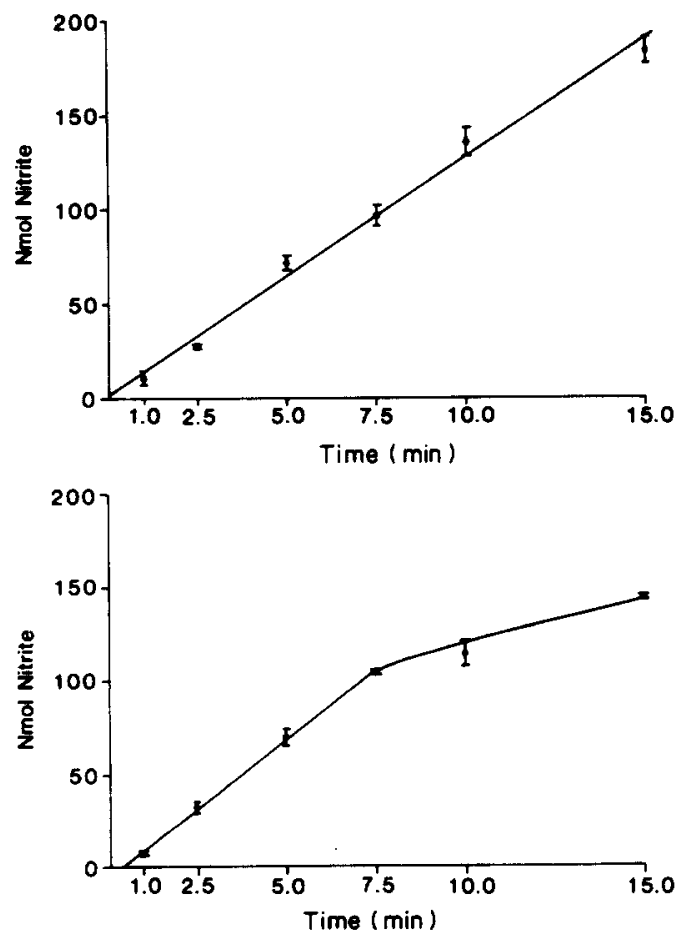

Fig. 4. Time dependence of 2NP denitrification. Assay conditions: buffer, $0.1 \mathrm{M}$ tris; microsomal protein, $1.0 \mathrm{mg} / \mathrm{ml}$; CHP, $3.0 \mathrm{mM}$; incubation time, $5 \mathrm{~min}$. Reaction mixture volumes for control and test flasks were adjusted to a final volume of $5.0 \mathrm{ml}$ in each case and $0.5 \mathrm{ml}$ aliquots removed for nitrite analysis at the appropriate time points. Each point represents mean activity $\pm \mathrm{SE}(n=3)$. Activity is expressed as nmol of nitrite released. Top: pH 7.6; 2NP, 262 mM. Bottom: pH 8.6; 2NP, $157 \mathrm{mM}$.

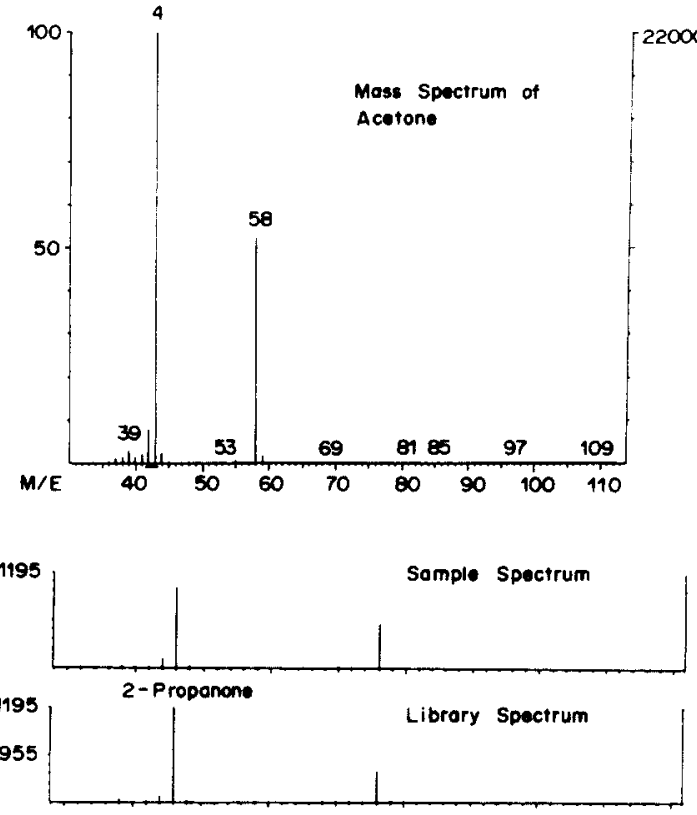

Fig. 5. Mass spectrum and computer library comparison of acetone produced during CHP-supported denitrification of 2NP. Enzyme assay and GC/MS conditions were as described in "Materials and Methods".

after $7.5 \mathrm{~min}$ at $\mathrm{pH} 8.6$ may be due to inactivation of P450 by a combination of high pH and CHP-induced lipid peroxidation over time with accompanying membrane disruption (Kulkarni and Hodgson, 1981). The routinely used $5 \mathrm{~min}$ reaction time is within the linear portion of the response curve in all the cases.

Under optimal conditions the specific activities observed for nitrite release were: 17.1 at $\mathrm{pH} 7.6$ and 16.3 at $\mathrm{pH}$ 8.6. Acetone was identified by $\mathrm{GC}$ and confirmed by MS as second product of the oxidative denitrification of 2NP (Fig. 5).

The results of the balance study are shown in Table 1 . A difference of over $200 \%$ between acetone production and nitrite release was observed. The possible reasons for this finding may involve the chemistry of nitrite and CHP and are discussed below.

The effects of chemicals known to modify the peroxygenase activity of $P 450$ were tested and the results are presented in Table 2 . The most effective inhibitor at both $\mathrm{pH} 7.6$ and $\mathrm{pH} 8.6$ was $n$ octylamine which inhibited the reaction by 30 and $41 \%$ respectively. Differential effects were seen for BHA and SKF-525A. BHA decreased activity $34 \%$ at $\mathrm{pH} 8.6$ but only $13 \%$ at $\mathrm{pH} 7.6$. SKF-525A, on the

Table 1. Nitrite and acetone production in CHP-supported denitrification of $2 \mathrm{NP}$

\begin{tabular}{cccc}
\hline & \multicolumn{2}{c}{ Specific activity } & \\
\cline { 2 - 3 } $\mathrm{pH}$ & Acetone & Nitrite & $\begin{array}{c}\text { Ratio } \\
\text { acetone/nitrite }\end{array}$ \\
\hline 7.6 & $16.50 \pm 0.70$ & $7.28 \pm 1.18$ & 2.27 \\
8.6 & $20.84 \pm 0.49$ & $8.65 \pm 0.70$ & 2.41 \\
\hline
\end{tabular}

Specific activity is expressed as nanomoles of acetone produced or nitrite released $/ \mathrm{min} / \mathrm{mg}$ protein. The concentration of $2 \mathrm{NP}$ used was $105 \mathrm{mM}$ (optimal concentrations: pH 7.6, $262 \mathrm{mM}$; pH 8.6,

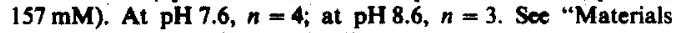
and Methods" for further details. 
Table 2. Effects of modifiers of $P 450$ peroxygenase activity on CHP-supported 2NP denitrification

\begin{tabular}{lcc}
\hline & \multicolumn{2}{c}{$\%$ of control } \\
\cline { 2 - 3 } \multicolumn{1}{c}{ Modifier } & $\mathrm{pH} 7.6$ & $\mathrm{pH} 8.6$ \\
\hline None & 100.0 & 100.0 \\
Imidazole $(1.0 \mathrm{mM})$ & $102.5 \pm 9.6$ & $104.9 \pm 13.2$ \\
$n$-Octylamine $(1.0 \mathrm{mM})$ & $70.2 \pm 3.6^{a}$ & $58.5 \pm 4.3^{a}$ \\
Metyrapone $(1.0 \mathrm{mM})$ & $92.8 \pm 4.1$ & $92.5 \pm 5.7$ \\
$\alpha$-Naphthoflavone $(0.2 \mathrm{mM})$ & $90.1 \pm 1.7$ & $103.5 \pm 8.2$ \\
Butylated hydroxyanisole $(0.1 \mathrm{mM})$ & $86.5 \pm 2.8$ & $66.0 \pm 7.1^{a}$ \\
SKF-525A (1.0 mM) & $76.5 \pm 3.5^{a}$ & $94.5 \pm 1.8$ \\
\hline
\end{tabular}

${ }^{a}$ Statistically different from control; $P \leq 0.01$.

Each value represents the mean $+\mathrm{SE}$ of determinations from four separate microsomal preparations. Mean specific activity for controls at $\mathrm{pH} 7.6$ was $17.5 \mathrm{nmol}$ of nitrite released $/ \mathrm{min} / \mathrm{mg}$ protein and at $\mathrm{pH} 8.6$ was $16.2 \mathrm{nmol}$ of nitrite released $/ \mathrm{min} / \mathrm{mg}$ protein.

other hand, produced $23 \%$ inhibition at $\mathrm{pH} 7.6$ but caused a non-significant decrease in activity at pH 8.6. No significant decrease in activity was observed with imidazole, metyrapone or $\alpha$-naphthoflavone.

\section{DISCUSSION}

Earlier, the involvement of $P 450$ in the metabolism of 2NP was clearly shown (Ullrich et al., 1978). However, the contribution of an oxidative mechanism in the overall denitrification process is difficult to assess in an NADPH-dependent microsomal system when oxygen-independent pathways are concurrently operative.

Ullrich et al. (1978) working with an NADPHdependent rat liver microsomal system, observed no change in nitrite release from 2NP when the oxygen concentration was reduced from 21 to $4 \%$. It is possible that $4 \%$ oxygen is sufficient for the NADPHdependent system to function at full capacity although a decrease in activity is more likely. Alternatively, a reductive mechanism similar to that postulated for nitrosamines by Appel, et al. (1982) may be operating. Of lesser importance is the contribution of hydrogen peroxide derived from the NADPH oxidase activity of $P 450$ which could promote oxidative metabolism of 2NP through the peroxygenase activity of P450 (Estabrook et al., 1984). It has been postulated that 2NP may cause hepatic lipid peroxidation (Zitting et al., 1981). The lipid peroxides formed during this process, in concert with preformed lipid peroxides, may contribute to a certain extent to oxidative metabolism of 2NP as has been demonstrated for benzo(a)pyrene (Morgenstern et al., 1981; Dix and Marnett, 1983). Lastly, if P450 were to act as a true peroxidase then a chain reaction mechanism analogous to that reported for 2NP metabolism by horseradish peroxidase (HRP) is also possible (Porter and Bright, 1983).

Our earlier work involving NADPH-dependent P450-mediated 2NP metabolism in uninduced mouse liver microsomes (Marker and Kulkarni, 1986) indicated that anaerobic conditions produce a substantial but not complete elimination of nitrite releasing activity. Decline in nitrite release due to anaerobiosis at $\mathrm{pH} 7.6$ was $83.7 \%$ and at $\mathrm{pH} 8.8$ was $74.4 \%$ suggesting that other oxygen-independent mechanisms for the metabolism of $2 \mathrm{NP}$ are operating in the presence of NADPH. The oxygen sensitivity of these reaction is unknown at present.

The ability of organic hydroperoxides such as CHP to replace NADPH, NADPH cytochrome $P 450$ reductase and molecular oxygen in microsomal $P$ 450-mediated metabolism has been recognized for some time (O'Brien, 1978). It has been suggested that $P 450$, in the presence of hydroperoxides, can perform all reactions typical of NADPH-dependent $P 450$ oxidative metabolism of xenobiotics with the possible exception of $N$-hydroxylation (O'Brien, 1978). The main advantage is that only oxidative reactions proceed in this system. Thus, a study of an oxidative pathway is possible without the interference of reductive mechanisms which apparently occur in an NADPH-supplemented microsomal system.

The investigations presented here describe for the first time denitrification of a nitroalkane (2NP) by hepatic microsomal P450 in the presence of the organic hydroperoxide, CHP. Specific activities of 17.1 and 16.3 at $\mathrm{pH} 7.6$ and 8.6 respectively were observed in CHP-supplemented hepatic microsomes from uninduced $\mathrm{CD}_{1}$ mice. In the NADPHdependent reaction, mouse hepatic microsomes exhibited maximal specific activities of about 8.0 and 6.4 at $\mathrm{pH} 7.6$ and $\mathrm{pH} 8.8$ respectively (Marker and Kulkarni, 1985, 1986). This is in contrast to Ullrich et al. (1978) who reported specific activities of 10 in PB induced rats and 0.5 in $3 \mathrm{MC}$ induced rats. Values for microsomes from untreated rats were not reported but were stated to be very low or undetectable.

The enzymatic nature of the CHP-supported reaction is evident from the observation that boiled microsomes reduce nitrite release to the nonenzymatic level. Linearity of the reaction with protein concentration and time also suggests an enzyme catalyzed reaction. Acetone, the expected second product of the oxidative denitrification of $2 \mathrm{NP}$, was identified by GC and confirmed by MS.

Under the conditions employed, known modifiers of $P 450$ mono-oxygenase/peroxygenase activity appear to be less effective inhibitors of 2NP denitrification than of other CHP-supported reactions. The inhibition patterns found in our experiments do not appear to be classifiable by the interaction of the inhibitor with $P 450$ (Type I vs Type II ligands). The most effective inhibitor, under the conditions used, was $n$-octylamine, a Type II compound, which produced a statistically significant inhibition of nitrite 
release at both $\mathrm{pHs}$ tested. Imidazole, another Type Il compound, however, was without effect.

Metyrapone and alpha-naphthoflavone also proved to be ineffective inhibitors. A widely range of values for inhibition by metyrapone of organic hydroperoxide-supported $P 450$ reactions have been reported (Rahimtula and O'Brien, 1974, 1976; Ashley and Griffin, 1981; Cederbaum, 1983). These values vary from $80 \%$ inhibition of CHP-supported aminopyrine $N$-demethylation by $0.1 \mathrm{mM}$ metyrapone (Ashley and Griffin, 1981) to only 25\% inhibition of $t$-butyl hydroperoxide and CHP-supported microsomal ethanol oxidation by $1.0 \mathrm{mM}$ metyrapone (Cederbaum, 1983). Taken together these reports suggest that the degree of inhibition due to any particular agent may be dependent on the substrate and the animal species in question.

The effectiveness of these inhibitors may also depend in part on the $P 450$ species involved in the reaction. The possible involvement of two or more P450 species in CHP-supported denitrification of 2NP is suggested by the presence of two peaks of activity at $\mathrm{pH} 7.6$ and 8.6. This is further supported by different optimal substrate concentrations at each $\mathrm{pH}$, and by $\mathrm{pH}$ dependent patterns of response to the inhibitors BHA and SKF-525A. SKF-525A showed a statistically significant inhibition of nitrite release at pH 7.6 but not at pH 8.6. BHA, which is metabolized by $P 450$ in a CHP-supported system (Rahimtula, 1983) displayed a significant inhibition only at pH 8.6. Differing patterns of BHA inhibition due to the participation of multiple isozymes in oxidative reactions have also been postulated by Yang et al. (1981) working with aryl hydrocarbon hydroxylase activity in hepatic microsomes from control animals or animals induced with $\mathrm{PB}, 3 \mathrm{MC}$ or 2,3,7,8-tetrachlorodibenzo- $p$-dioxin. Varying affinities of different $P 450$ species for metyrapone have also been postulated by Cinti (1978). Similar responses to changes in $\mathrm{pH}$, substrate concentration and inhibitors observed in the NADPH-dependent reaction also implicate involvement of multiple forms of $P 450$ in the denitrification of 2NP in uninduced mouse liver microsomes (Marker and Kulkarni, 1986). This contention is further supported by a report on the varying effectiveness of NADPH-dependent denitrifcation of 1-nitropropane and nitroethane by different reconstituted isozymes of $P 450$ (Sato et al., 1982).

The balance study of acetone production to nitrite release in the CHP-supproted reaction (Table 1) produced unexpected results. Since the presence and purity of acetone were confirmed by MS, the imbalance in the stoichiometry of acetone: nitrite production may be due to sequestration of nitrite in the reaction mixture. The results of a recent study (Pryor et al., 1985) investigating nitrosation of organic hydroperoxides provide, in part, a possible explanation for the presumed nitrite sequestration. These authors showed that, in hexane, CHP will react within seconds with an $\mathrm{NO}_{2} / \mathrm{N}_{2} \mathrm{O}_{4}$ mixture to form cumylnitrate, cumylnitrite, cumylalcohol and acetophenone in ratios of $58: 13: 11: 17$ respectively. The mixture of $\mathrm{NO}_{2} / \mathrm{N}_{2} \mathrm{O}_{4}$ can be obtained from nitrite or nitrous acid through an $\mathrm{N}_{2} \mathrm{O}_{3}$ intermediate (Anonymous, 1981). It is thus possible that a significant portion of the total nitrite generated during denitrification may be reacting with $\mathrm{CHP}$ and be undetectable by the methods employed. The possibility also exists that nitrite may be reacting in a similar fashion with lipid peroxides formed by the interaction of CHP with microsomal lipids and this may in part explain the difference in the acetone/nitrite ratio. Similarly lipid peroxide radicals produced by interaction of CHP with microsomal membranes could also interact with an $\mathrm{NO}_{2}$ radical (Pryor et al., 1982) contributing to the nitrite loss. It appears from this discussion that several secondary products may be generated and further studies are needed to identify and quantitate these products.

It is proposed that the first step in the mechanism for the CHP-supported oxidative denitrification of 2NP involves the peroxygenase activity of $P 450$. However, the possibility of a subsequent or concurrent chain reaction mechanism similar to that reported for 2NP metabolism by HRP cannot be discounted at present (Porter et al., 1983). HRP Compound I was reported to initiate a chain reaction resulting in nitrite and acetone as products. The reaction, however, depended on the presence of propane-2-nitronate. This species is derived from $2 \mathrm{NP}$ but the equilibrium has a $t_{1 / 2}$ of $150 \mathrm{~min}$ at $\mathrm{pH} 5.0$ and thus is unlikely to contribute significantly to acetone production or nitrite release in the $5 \mathrm{~min}$ reaction time used in our study.

\section{CONCLUSION}

The evidence presented indicates that $P 450$ mediated oxidative metabolism of 2NP occurs in CHP-supplemented hepatic microsomes from uninduced $C D_{1}$ mice. The observed stoichiometry suggests that the specific activity based on acetone produced is the appropriate measure of 2NP denitrification in the CHP supported system since nitrite appears to be sequestered in the reaction mixture. The results suggest the generation of yet unidentified products resulting from secondary reactions of the unaccounted nitrite released. The possibility of a chain reaction mechanism in the CHP supported denitrification reaction exists but seems unlikely. It is suggested that, through the peroxygenase activity of $P 450$, oxygen from $\mathrm{CHP}$ is introduced into $2 \mathrm{NP}$ possibly through a hydroxylated intermediate as suggested by Ullrich et al. (1978). Rearrangement of the unstable intermediate produces acetone with concommitant release of nitrite. This is supported by the identification of nitrite and acetone as the products in the CHP system. This does not imply, however, that the NADPH-dependent denitrification of $2 \mathrm{NP}$ in uninduced $C D_{1}$ mouse liver microsomes is solely oxidative.

\section{SUMMARY}

Cytochrome $P-450(P 450)$ mediated denitrification of 2-nitropropane (2NP) was studied in cumene hydroperoxide (CHP) supplemented hepatic microsomes from male $C_{1}$ mice. Under optimal conditions, the mean specific activities of 17.1 and $16.3 \mathrm{nmoles}$ of nitrite released $/ \mathrm{min} / \mathrm{mg} \mathrm{microsomal}$ protein were observed at $\mathrm{pH} 7.6$ and 8.6 , respectively. The oxidative metabolism of $2 \mathrm{NP}$ produced two 
peaks of nitrite releasing activity at $\mathrm{pH} 7.6$ and 8.6, each with its own substrate optimum. SKF-525A and butylated hydroxyanisole, known modifiers of $P 450$ peroxygenase activity, exhibited differential inhibitory effects dependent on $\mathrm{pH}$. These results suggest the involvement of multiple $P 450$ isozymes in the denitrification of 2NP. Acetone was identified as the second product of the reaction and its accumulation was more than 2 times the amount of nitrite observed suggesting the sequestration of nitrite by components of the reaction mixture leading to unidentified metabolites of 2NP. Thus, it appears that microsomal denitrification of $2 \mathrm{NP}$ in the presence of CHP is precisely monitored by acetone production rather than by quantification of nitrite released.

Acknowledgement-This work was supported in part by grant T32ES07062 from the United States Public Health Service, National Institutes of Health.

\section{REFERENCES}

Anonymous (1981) The health effects of nitrate, nitrite and $N$-nitroso compounds: Part 1 of a 2 part study by the committee on nitrite and alternative curing agents in food. Assembly of Life Sciences, National Academy Press, Washington, D.C.

Appel K. E. and Graf H. (1982) Metabolic nitrite formation from $N$-nitrosamines: Evidence for a cytochrome $P-450$ dependent reaction. Carcinogenesis 3, 293-296.

Appel K. E., Schrenk D., Schwarz M., Mahr B. and Kunz W. (1980) Denitrosation of $N$-nitrosomorpholine by liver microsomes: Possible role of cytochrome $P-450$. Cancer Lett. 9, 13-20.

Ashley P. L. and Griffin B. W. (1981) Involvement of radical species in the oxidation of aminopyrine and 4-aminoantipyrine by cumene hydroperoxide in rat liver microsomes. Molec. Pharmac. 19, 146-152.

Cederbaum A. I. (1983) Organic hydroperoxide-dependent oxidation of ethanol by microsomes: Lack of a role for free hydroxyl radicals. Archs Biochem. Biophys. 227, 329-338.

Cinti D. (1978) Agents activating the liver microsomal mixed function oxidase system. Pharmac. Ther. A2, 727-749.

Dix T. A. and Marnett L. J. (1983) Metabolism of polycyclic aromatic hydrocarbon derivatives to ultimate carcinogens during lipid peroxidation. Science 221, 77-79.

Estabrook R. W., Martin-Wixtrom C., Saeki Y., Renneberg R., Hildebrandt, A and Werringloer J. (1984) The peroxidatic function of liver microsomal cytochrome $P-450$ : Comparison of hydrogen peroxide and NADPHcatalysed $N$-demethylation reactions. Xenobiotica 14, 87-104.

Fouts J. R. and Brodie B. B. (1957) The enzymatic reduction of chloramphenicol, $p$-nitrobenzoic acid and other aromatic nitro compounds in mammals. J. Pharmac. exp. Ther. 119, 197-207.

Gornall A. G., Bardwill C. S. and David M. M. (1949) Determination of serum proteins by means of the Biuret reaction. J. biol. Chem. 177, 751-766.

Jonsson J., Kammerer R. C. and Cho A. K. (1977) Metabolism of 2-nitro-1-phenylpropane to phenylacetone by rabbit liver microsomes. Res. Communl chem. Path. Phar mac. 18, 75-82.

Kulkarni A. P. and Hodgson E. (1981) A comparison of NADPH and cumene hydroperoxide-stimulated lipid peroxidation in mouse hepatic microsomes. Int. J. Biochem. 13, 811-816.

Marker E. K. and Kulkarni A. P. (1985) Enzymatic denitrification of 2-nitropropane in uninduced mouse liver microsomes. Toxic. Lett. 26, 181-185.

Marker E. K. and Kulkarni A. P. (1986) Cytochrome $P-450$ mediated denitrification of 2-nitropropane in mouse liver microsomes. J. Biochem. Toxic. Submitted.

Morgenstern R., DePierre J. W., Lind C., Guthenberg C., Mannervik B. and Ernster L. (1981) Benzo(a)pyrene quinones can be generated by lipid peroxidation and are conjugated with glutathione by glutathione-S-transferase B from rat liver. Biochem. biophys. Res. Commun. 99, $682-690$.

O'Brien P. J. (1978) Hydroperoxides and superoxides in microsomal oxidations. Pharmac. Ther. A2, 517-536.

Porter D. J. T. and Bright H. J. (1983) The mechanism of oxidation of nitroalkanes by horseradish peroxidase. $J$. biol. Chem. 258, 9913-9924.

Pryor W. A., Lightsey J. W. and Prier D. O. (1982) The production of free radicals in vivo from the action of xenobiotics: The initiation of autoxidation of polyunsaturated fatty acids by nitrogen dioxide and ozone. In Lipid Peroxides in Biology and Medicine (Edited by Yagi K.), pp. 1-14. Academic Press, New York.

Pryor W. A., Castle L. and Church D. F. (1985) Nitrosation of organic hydroperoxides by nitrogen dioxide/dinitrogen tetraoxide. J. Am. Chem. Soc. 107, 211-217.

Rahimtula A. (1983) In vitro metabolism of 3-t-butyl-4-hydroxyanisole and its irreversible binding to proteins. Chem.-Biol. Int. 45, 125-135.

Rahimtula A. D. and O'Brien P. J. (1974) Hydroperoxide catalyzed liver microsomal aromatic hydroxylation reactions involving cytochrome P450. Biochem. biophys. Res. Commun. 60, $440-447$

Rahimtula A. D. and O'Brien P. J. (1976) The peroxidase nature of cytochrome $P 450$. In Microsomes and Drug Oxidations (Edited by Ullrich V., Roots I., Hildebrandt A., Estabrook R. W. and Conney A. H.), pp. 210-216.

Remington R. R. and Schork M. A. (1970) Statistics with Applications to the Biological and Health Sciences. Prentice-Hall, Englewood Cliffs, N.J.

Sakurai H., Hermann G., Ruf H. H. and Ullrich V. (1979) The interaction of aliphatic nitro compounds with the liver microsomal monooxygenase system. Biochem. Pharmac. 29, 341-345.

Sato R., Aoyama T. and Imai Y. (1982) Multiple forms of cytochrome $P-450$ from liver microsomes of druguntreated rabbits: Purification and characterization. In Oxygenases and Oxygen Metabolism (Nozaki M., Yamamoto S., Ishimura Y., Coon M. J., Ernster L. and Estabrook R. W.), pp. 321-332. Academic Press, New York.

Ullrich V., Hermann G. and Weber P. (1978) Nitrite formation from 2-nitropropane by microsomal monooxygenases. Biochem. Pharmac. 27, 2301-2304.

Yang C. S., Sydor W., Martin M. B. and Lewis K. F. (1981) Effects of butylated hydroxyanisole on the aryl hydrocarbon hydroxylase of rats and mice. Chem.-Biol. Int. 37, 337-350.

Zitting A., Savolainen H. and Nickels J. (1981) Acute effects of 2-nitropropane on rat liver and brain. Toxic. Lett. 9 , 237-246. 